\title{
Green Building Assessment Based on Energy Efficiency and Conservation (EEC) Category at Pascasarjana B Building Diponegoro University, Semarang
}

\author{
Rahayu Indah Komalasari ${ }^{1, *}$, P. Purwanto ${ }^{1,2}$, S. Suharyanto ${ }^{3}$ \\ ${ }^{1}$ Graduate Program on Environmental Studies, Diponegoro University, Semarang, Indonesia \\ ${ }^{2}$ Department of Chemical Engineering, Faculty of Engineering Diponegoro University, Semarang, Indonesia \\ ${ }^{3}$ Department of Civil Engineering, Faculty of Engineering Diponegoro University, Semarang, Indonesia \\ *Corresponding author: rahayu.ik@gmail.com
}

Received March 19, 2014; revised April 08, 2014; accepted April 22, 2014

\begin{abstract}
Green building is a concept in which development should be implemented with environmental principles, start from design, construction, operation, and management. There is a Green Building Council Indonesia (GBCI) as a certification body for Green Building that established a Greenship New Building (NB) Version 1.2 as rating tools for green building assessment for new buildings in 2013. One of the categories that assessed is Energy Efficiency and Conservation (EEC). This study was conducted to determine how EEC criteria applied at Pascasarjana B Building Diponegoro University, by measuring the criteria based on Greenship NB Vers 1.2. The method of this study is comparing the existing condition of building with Greenship rating tools in order to know the points that would gained. The measurement of some criteria based on Indonesia National Standards and Ministry Regulation. From the results of the study, The Pascasarjana B Building Diponegoro University earns 10 points out of a total 26 points, or approximately $38.46 \%$ rating level for EEC. This baseline points obtained from some criteria such OTTV, Ventilation and Climate Change Impact. This study also gives recommendations output for compliance and building improvement to enhance the points based on Greenship rating tools.
\end{abstract}

Keywords: Green Building, Greenship, Energy Efficiency and Conservation (EEC), criteria, point

Cite This Article: Rahayu Indah Komalasari, P. Purwanto, and S. Suharyanto, "Green Building Assessment Based on Energy Efficiency and Conservation (EEC) Category at Pascasarjana B Building Diponegoro University, Semarang.” American Journal of Energy Research, vol. 2, no. 2 (2014): 42-46. doi: 10.12691/ajer-2$2-4$.

\section{Introduction}

Nowadays, green building concept is a need for building development. Buildings account for more than $40 \%$ of all global carbon dioxide emissions, one of the main culprits implicated in the phenomenon of global warming [1]. Energy consumption in buildings greatly affects the $\mathrm{CO}_{2}$ emissions into the air. The concentration of $\mathrm{CO}_{2}$ in the atmosphere continues to grow and cause the greenhouse effect which can increase the temperature of the earth. This condition has led to the phenomenon of global warming. Although the increase in $\mathrm{CO} 2$ is not the only cause of global warming, but the problem of energy consumption is becoming global issue.

To prevent global warming, there needs to be new practices, from the design phase to the operation of the building in order to increase the efficiency of energy consumption, so that the carbon footprint, global warming potential and ozone depletion potential can be reduced.

Indonesia government by The Ministry of Environment issues Ministerial Regulation No. 08/2010 on The Criteria and Certification of Green Building. The Government needs to encourage and facilitate the initiative of stakeholders in making effort to mitigate and adapt to climate change by managing green buildings [2]. This regulation becomes one of guidelines to create the categories for green buildings in Indonesia.

Green Building Council Indonesia (GBCI) as a certification body in Indonesia which is registered by The Ministry of Environment has issued a Greenship New Building (NB) Version 1.2 as a rating tools for green building assessment for new buildings. There are 7 categories of the rating tools which are accordance with regulations in Indonesia.

One of the categories that analyze in this study is Energy Efficiency and Conservation (EEC). This assessment was conducted to determine how EEC criteria applied at Pascasarjana B Building Diponegoro University, by measuring the criteria based on Greenship NB Version 1.2. The result of this assessment is not only to define the points, but also give recommendation for improving performance of building. Therefore the building management could establish further internal regulation and policy for better environment. 


\section{Literature Review}

\subsection{Green Building}

Based on regulation in Indonesian, green building can be defined as building applying environmental principles in its design, construction, operation and management along within significant aspect of handling the impact of climate change [2].

Environmental Protection Agency (EPA) describe that buildings have an enormous impact on the environment, human health, and the economy. The successful adoption of green building strategies can optimizee both the economic and environmental performance of buildings [3].

Nowadays, in several countries there are institutions and Green Building standards, namely BREEAM (UK), LEED (United States), NABERS and GREEN STAR (Australia), GREEN MARK (Singapore) and also GREENSHIP from Indonesia [4]. The standards have different criteria and assessment, depending on the critical issues emerging in that country and based on the regulations. The benefit which might be rating tools acquired from Green Building certification are not only as a form of business environmental compliance but also as an improvement image and public perception, which consequently constitute the market value compared to conventional building.

\subsection{Greenship}

Greenship from GBCI has 2 types of rating tools, which are Greenship for existing building and new building. Pascasarjana B Building is a building that has a operational time under 3 years, so it can be classified into a new building types. According to the standard, there are 7 categories with total 100 points achievement (100\%) which namely Appropriate Site Development (17\%), Energy Efficiency and Conservation (26\%), Water Conservation (20\%), Material Resources and Cycle (14\%), Indoor Health and Comfort (10\%), Building Environment and Management (13\%). The Energy Efficiency and Conservation has the biggest point for Greenship.

Energy Efficiency and Conservation (EEC) contains 2 criteria prerequisite, i.e. electrical Sub metering and OTTV Calculation, 1 criteria bonus is On Site Renewable Energy and also 4 criteria credit which have 26 points maximum. These criteria are Energy Efficiency Measure, Natural Lighting, Ventilation, and Climate Change Impact [5].

Tabel 1. Point of Energy Efficiency and Conservation (EEC)

\begin{tabular}{cc} 
Tabel 1. Point of Energy Efficiency and Conservation (EEC) \\
\hline Criteria & Max Poin \\
\hline Electrical Sub metering & Prerequisite \\
OTTV Calculation & Prerequisite \\
Energy Efficiency Measure & 20 \\
Natural Lighting & 4 \\
Ventilation & 1 \\
Climate Change Impact & 1 \\
On Site Renewable Energy (Bonus) & 5 \\
\hline
\end{tabular}

Source: GBCI, 2013

\subsection{Energy Efficiency Measure}

The objective for this criterion is to encourage savings in energy consumption through the application of energy efficiency measure. There are 4 sub-criteria for each component, inter alia OTTV measurement, artificial lighting, vertical transportation, and air condition system.

Overall Thermal Transfer Value (OTTV) is a measure of average heat gain into a building through the building envelope. In order to get value for the heat gain, we use National Standard [6]:

$$
\begin{gathered}
\text { OTTV }=\alpha\left[\left(U_{w} \times(1-W W R)\right] \times T D_{E q}\right. \\
+(S C \times W W R \times S F) \\
O T T V=\frac{\left(\mathrm{A}_{01} \times \mathrm{OTTV}_{1}\right)+\ldots \ldots+\left(\mathrm{A}_{\mathrm{oi}} \times \mathrm{OTTV}_{\mathrm{i}}\right)}{A_{01}+\ldots \ldots+A_{o i}}
\end{gathered}
$$

where:

$\alpha$ : absorptivity of opaque wall

$\mathrm{U}_{\mathrm{w}}$ : thermal transmittance of opaque wall $\left(\mathrm{W} / \mathrm{m}^{2} \mathrm{~K}\right)$

WWR: window-to-wall ratio

$\mathrm{TD}_{\mathrm{Eq}}$ : equivalent temperature difference $(\mathrm{K})$

SC: shading coefficient of fenestration

$\mathrm{SF}$ : solar factor for vertical surface $\left(\mathrm{W} / \mathrm{m}^{2}\right)$

$\Delta \mathrm{T}$ : temperature difference indoor and outdoor $(5 \mathrm{~K})$

An: area of opaque wall $\left(\mathrm{m}^{2}\right)$

National standard in Indonesia set maximum limits for OTTV at $35 \mathrm{~W} / \mathrm{m}^{2}$ per year [8], whereas in some countries such as Hongkong Government set a maximum limit of 24 $\mathrm{W} / \mathrm{m}^{2}$ per year. [6]

\section{Research Method}

The method of this study is comparing the existing condition of building with Greenship rating tools in order to know the points that would gained. The computer software used to calculate the criteria are, Microsoft Office Excel 2007 and Sketch Up Pro 8. There are many programs for Building Energy Simulation, such as Energy-10, DOE-2, Energy Plus, Ecotech, etc.

The measurement of some criteria are based on Indonesia National Standards (SNI) and Ministerial Regulations. These criteria are OTTV calculation and energy efficiency measure. The first step to calculate OTTV is making the building design into 3D model by using Sketch Up Software to get information about surface area and fenestration. Then the heat gain for each façade area can be calculated using Eq. (1) and total average surface area using Eq. (2).

Natural lighting and ventilation can be measured by observation and direct measurement. Especially for natural lighting, the sample points scattered all over the floor with a total of 8 points and measured by Luxmeter for 3 times a day, which is in the morning, noon and evening. Result of this measurement is calculated by Microsoft Excel 2007.

Electrical sub metering availability can be determined from interview with building management and electrician. The climate change impact determined by calculating $\mathrm{CO} 2$ emissions that can be measured by Spreadsheet from ICLEI and GIZ Indonesia. The supporting data for this calculation is obtained from energy use (kWh) per year in the building multiplied by conversion (emission) factor of $0.73 \mathrm{t}-\mathrm{CO}_{2} / \mathrm{MWh}$.

The criteria calculation, can be done in the Ms. excel worksheet because the data are few and simple measurement 


\section{Result}

Pascasarjana B Building is located in Pleburan Campus, into one area with Pascasarjana A Building. The B Building is south-headed orientation, it consists of six floors with gross area of 4,289 meter square. This building has approximately 372 occupants and the operational hour is 8 hours per day.

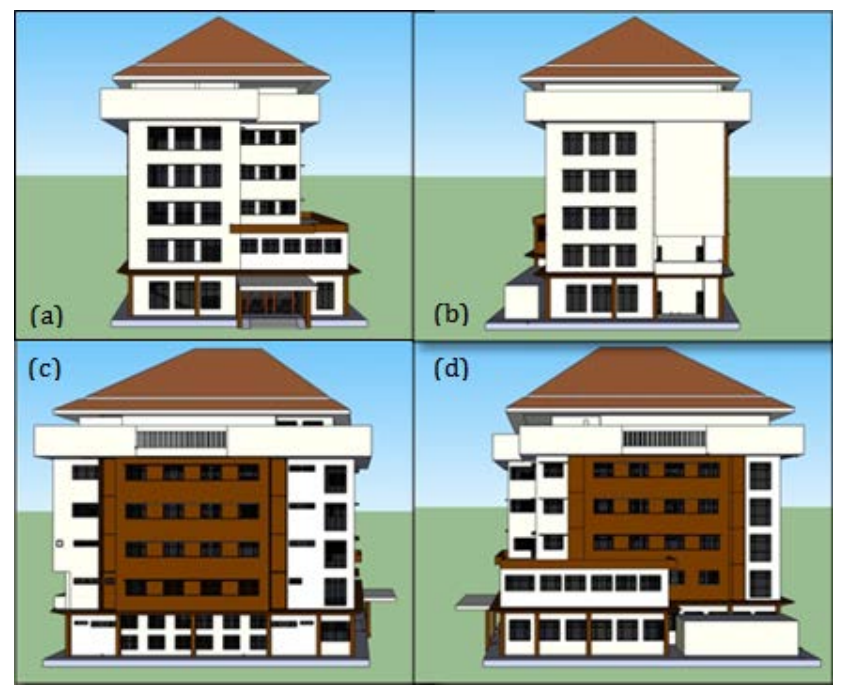

Figure 1. Sketch Up 3D (a) South; (b) North; (c) West; (d) East

Energy use in the building is represented in the form of IEC (Intensity of Energy Consumption). From the data during 2013, IEC average of Pascasarjana B Building amounted to $58.56 \mathrm{kWh} / \mathrm{m}^{2}$ per year or $4.65 \mathrm{kWh} / \mathrm{m} 2$ per month. This evaluation results indicate the IEC electricity is eligible electric energy-saving and highly efficient classified according to the guidelines for the use of electricity to office buildings of the Ministry of National Education of Indonesia. Annual IEC in Indonesia defined $240 \mathrm{kWh} / \mathrm{m}^{2}$ per year, and for the Green Mark Singapore, IEC defined $215 \mathrm{kWh} / \mathrm{m}^{2}$ per year [7]. Although higher standards in Singapore, but the results shows that the building is still allowed to the maximum limit of the standard.

\subsection{EEC Prerequisite}

The prerequisite is a mandatory criteria that should be fulfilled before implementing assessment at another criteria. The prerequisite are installing the electrical submeter system and performing the OTTV calculation based on national standard for Energy Conservation of Building Envelope on Building [8]. The electrical sub-meter system aims to measure electrical consumption in each group of loads and equipment systems, including HVAC system, lighting system and other power system. In the building studied, the sub-meter system have not installed yet.

While the existing condition of OTTV average value of the building studied is amounted of $32.95 \mathrm{~W} / \mathrm{m}^{2}$ from southern orientation which is the national standard allowed is $35 \mathrm{~W} / \mathrm{m}^{2}$.

\subsection{Energy Efficiency Measure}

Energy efficiency measure criteria in this category have the highest points. Related with large energy consumption in a building, therefore there needs to be an effort to encourage energy savings through efficiency measures and conservation. Each standard has different criteria and assessment, depending on the critical issues emerging in the country. Indonesia set maximum standards for OTTV for $35 \mathrm{kWh} / \mathrm{m}^{2}$ per year. Whereas in some countries such as Hongkong set a maximum OTTV for $24 \mathrm{kWh} / \mathrm{m}^{2}$ per year.

There are 3 options to measuring in these criteria. Option 1, by using simulation modelling software, for examples: Energy-10, DOE-2, Energy Plus, BLAST, Ecotech, etc. the weakness of energy modelling is most of this software is quite complicated. It is better to use this software start from design phase. Option 2, by using worksheet excels from Greenship to calculate the energy consumption for each electrical system. The last is by measuring the component manually. The authors take the last one, because the data about building is very limited, so that the calculating result will be found much difficulty.

There are the benchmarks with a variety of alternative assessment. The Energy Efficiency Measure in Building B can be assessed by separately calculate of each component due to its integrity electricity meter system. The measures are as follows:

\subsubsection{OTTV}

There are three points for the OTTV value under the maximum standard. Moreover, 2 points maximum for the OTTV reduction for every $2.5 \%$. The steps of this calculation are determine area of opaque wall (Aw) and window to wall ratio, find $\alpha$ value, calculate thermal resistance, determine shading coefficient, solar factor and temperature equivalent, calculate the OTTV partial and calculate OTTV total [8].

There are three major components involved in OTTV calculation: (i) conduction through opaque wall, (ii) conduction through fenestration, (iii) solar radiation through fenestration.

Areas of opaque wall Pascasarjana B Building are consisting of two colours of wall, ivory and brown that has total area of $2734.51 \mathrm{~m}^{2}$. The building is formed of a plastered brick wall of $150 \mathrm{~mm}$ thickness, $0.77 \mathrm{~W} / \mathrm{mK}$ thermal resistances and coated with $15 \mathrm{~mm}$ of wall plaster. This wall plaster has $0.57 \mathrm{~W} / \mathrm{mK}$ thermal conductivity and thermal resistance for external and internal surface amounted of $0.040 \mathrm{~m}^{2} \mathrm{~K} / \mathrm{W}$ and $0.130 \mathrm{~m}^{2} \mathrm{~K} / \mathrm{W}$. Therefore the total thermal resistance is $0.369 \mathrm{~m}^{2} \mathrm{~K} / \mathrm{W}$, so it has $2.710 \mathrm{~W} / \mathrm{m}^{2} \mathrm{~K}$ of $\mathrm{U}$-value. The colours affect $\alpha$ value, so that ivory has 0.595 and the brown one has 0.745 . According to this result, temperature equivalent for the wall is $10 \mathrm{~K}$.

Solar factor in Indonesia are determined as 130 of northern, 112 of eastern, 97 of southern and 243 of western. Areas of total fenestration of Pascasarjana B Building are $626.05 \mathrm{~m}^{2}$ with 21 types of window size. Technical characteristic for shading coefficient of $5 \mathrm{~mm}$ window glazing is 0.69 (Panasap Dark type).

Based on the equations, here is the result for total heat gain:

Conduction through opaque wall $=47,549.29 \mathrm{~W}$

Conduction through fenestration $=46,708.81 \mathrm{~W}$

Solar radiation through fenestration $=16,527.72 \mathrm{~W}$

So that OTTV for each orientation, are:

Southern OTTV $=31.05 \mathrm{~W} / \mathrm{m}^{2}$

Northern OTTV $=28.61 \mathrm{~W} / \mathrm{m}^{2}$ 
Eastern OTTV $=28.53 \mathrm{~W} / \mathrm{m}^{2}$

Western OTTV $=41.82 \mathrm{~W} / \mathrm{m}^{2}$

Total OTTV southern-headed $=32.95 \mathrm{~W} / \mathrm{m}^{2}$

According to the result above, this building has 32.95 $\mathrm{W} / \mathrm{m}^{2}$ of OTTV or $5.86 \%$ decreasing. With the result above, the building gets 5 points.

\subsubsection{Lighting}

The first benchmarks of artificial lighting is using the building lights with $15 \%$ more efficient than lighting power listed in national standard on energy conservation at lighting system [9]. The second benchmark is using $100 \%$ high frequency ballasts (electronic) for workspace. In this case, the benchmark is fulfilled due to lights used in the building which using the compact fluorescent PLC lamp type that listed as energy saving lamp. The third benchmark is the zoning for the entire workspace lighting associated with the motion sensor. All of the room in Building B, utilize the switch for lighting. No motion sensor and light sensor used in the building. The fourth benchmark is the placement of light switches within reach of the hand when the doors open has been fulfilled. In each classroom, the light switch located near the entrance, so it can still be out of reach when opening the door. According to the benchmarks above, the building gets 2 points.

\subsubsection{Vertical Transportation}

The benchmark for vertical transportation in building is using energy saving features on the lift. Lift is one of the equipment that requires enormous energy in a building. The existing building provided by two Hyundai lift with capacity 10 people that equivalent to $680 \mathrm{~kg}$ load. Lift are equipped with gearless machine that can save up to $25 \%$ of energy (energy saving). Therefore this benchmark gets one point.

\subsubsection{Air Condition System}

The benchmark for air condition system criterion is using air conditioning equipment with minimum Coefficient of Performance (COP) 10\% larger than the standard as stated in national standard for energy conservation on HVAC system building [10]. The existing condition, the AC used is split type air conditioner which has a capacity of $24,000 \mathrm{btu} / \mathrm{hr}$, so that COP minimum efficiency specified in standard in the form is at 2.6.

Panasonic AC 24KKP type, based on the technical specifications product has a COP value of 2.7 or only worth $3.8 \%$ higher than the standard. While specified that the minimum COP greater $10 \%$, so this points was null.

\subsection{Natural Lighting}

The optimum use of natural lighting amount $30 \%$ of floor space working areas obtains at least 300 lux. The lighting measurement done manually by Luxmeter, showed that only the primary classrooms $(301,401,501)$ at the noon that meet the benchmarks of light intensity. While the other room have the light intensity below 300 lux. Therefore, for these benchmarks, the building does not get any point.
Tabel 2. Result of lighting measurement (lux)

\begin{tabular}{ccccc}
\multicolumn{5}{c}{ Tabel 2. Result of lighting measurement (lux) } \\
\hline No. & Room & Morning & Noon & Evening \\
\hline 1. & Library A & 110,67 & 368,58 & 134,67 \\
2. & Library B & 39,58 & 51,67 & 57,58 \\
3. & B. 301 & 232,92 & 265,92 & 233,92 \\
4. & B. 401 & 137,08 & 249,83 & 152,00 \\
5. & B. 402 & 112,08 & 135,08 & 123,08 \\
6. & B. 408 & 49,00 & 54,75 & 52,42 \\
7. & B. 501 & 145,17 & 205,92 & 154,17 \\
8. & B.603 & 37,25 & 104,25 & 91,25 \\
\hline Source: primary data, 2013 & & &
\end{tabular}

\subsection{Ventilation}

There are no air conditionings (AC) within toilets, stairs, corridors, and elevator lobbies and yet equipped with natural or mechanical ventilation. Pascasarjana B Building complements public spaces such as the lobby lift, stairs, toilets and corridors with natural and mechanical ventilation, thereby able in reducing energy consumption and encouraging the use of efficient ventilation in buildings. This benchmarks point is 1 .

\subsection{Climate Change Impact}

Climate Change Impact can be measure by submitting the calculation of $\mathrm{CO}_{2}$ emission reductions obtained from the difference between the energy needs of designed baseline building using the grid emission factor as stated in the DNA Decree on B/277/Dep. III/LH/01/2009. The analysis of $\mathrm{CO} 2$ emission is calculated from the data of electrical energy consumption. The existing building electricity based on 2013 data is accounted of 251,113 $\mathrm{kWh}$ per year, which is equivalent to 183 tonnes of $\mathrm{CO}_{2}$ eq per year.

\section{Conclusion}

There is one of two prerequisites which is not met criteria due to the unavailability of electrical sub-meter system. Total OTTV is $32.95 \mathrm{~W} / \mathrm{m}^{2}$ which is eligible below the the maximum standard in Indonesia. Lighting and vertical transportation are met the benchmarks as an electrical energy saving equipment. The air condition system is not fulfilling the criteria due to the percentage of COP that under the minimum standard. So did the natural lighting, from direct measurement it could not meet the standard. The criteria for ventilation and climate change impact already meet the standard of each criterion. The last, for the bonus criteria could not be achieved due to the unavailability of renewable energy system in this building. Therefore, the total points that Pascasarjana B Building earned from all criteria is 10 points. This means that the building achieved $38.46 \%$ of total category points.

The recommendations which can be given to increase the points are: (i) installing electrical sub-meter system type (kWh meter) to meet the prerequisite criteria, (ii) rreplacing the existing AC with more energy efficient type (high COP), (iii) replacing the glass type with the clearer one and rearranging the classroom component to gain better illumination surface area, (iv) utilizing the renewable energy sources as an alternative energy in the building. 


\section{Acknowledgement}

The author would like to thank Beasiswa Unggulan from Bureau of Planning and International Cooperation, The Ministry of National Education for the scholarship. The author also thank to Mr. Eddy Indarto (Laboratory Graphic and Design on Department of Architecture Engineering Undip) for assistance with Building Envelope and OTTV.

\section{References}

[1] Yudelson, Jerry, Green Building A to Z; Understanding The Language of Green Building, New Society Publisher, Canada, 2007, p. 3.

[2] Indonesia Ministry of Environment, Ministerial Regulation No. 08/2010 on The Criteria and Certification of Green Building, 2010.
[3] www.epa.gov/greenbuilding/pubs/whybuild.htm 2014/03/13).

[4] Karyono, T.H, Green Architecture: Pengantar Pemahaman Arsitektur Hijau di Indonesia, Rajawali Pers, Jakarta, 2010.

[5] Green Building Council Indonesia, Greenship Rating Tools for New Building Verse 1.2, Green Building Council Indonesia, Jakarta, 2013.

[6] Chan, ALS., TT.Chow, Evaluation of Overall Thermal Transfer Value (OTTV) for Commercial Buildings Constructed with Green Roof, Applied Energy 107, 2013, p. 10-24.

[7] BCA, Green Mark for Non Residential Existing Building Vers.NREB 2.1, Singapore, 2009.

[8] Badan Standarisasi Nasional, SNI 03-6389-2011 tentang Konservasi Energi Selubung Bangunan pada Bangunan Gedung, Jakarta, 2011.

[9] Badan Standarisasi Nasional, SNI 03-6197-2011 tentang Konservasi Energi pada Sistem Pencahayaan, Jakarta, 2011.

[10] Badan Standarisasi Nasional, SNI 03-6390-2011 tentang Konservasi Energi Selubung Bangunan pada Sistem Tata Udara Bangunan Gedung, Jakarta, 2011. 